\title{
Environmental impact of corporate social responsibility
}

\author{
Anica Hunjet ${ }^{1,}{ }^{*}$, Valentina Jurinić ${ }^{1}$, and Dijana Vuković $^{2}$ \\ ${ }^{1}$ University North, Croatia, 104. Brigade 3, 42000 Varaždin, Croatia \\ ${ }^{2}$ University North, Croatia, 104. Brigade 1, 42000 Varaždin, Croatia
}

\begin{abstract}
.
Research background: Corporate social responsibility (CSR) involves doing business in an ethical manner, being responsible to employees, customers and stakeholders in the business, and contributing to society and social causes. Organisations that implement CSR in their business have the potential to become more competitive in the market, and to create a better image of themselves in public. An organisation should behave in a socially acceptable manner towards interest groups affected by its business, since the behaviour of those interest groups also has an impact on the organisation's operations.

Purpose of the article: This article covers the economic, social, environmental and ethical dimensions of CSR, and focuses on the care for the environment and the impact of the application of CSR on the success of the organisation.

Methods: The aim of the research is to investigate how the application of CSR in the organisation affects its performance factors but also its environment and whether the organisation can in addition to achieving its primary objective - profit, also contribute to a better and healthier environment for future generations.

Findings \& Value added: It can be concluded from the research results that people prefer working in an organisation that is socially responsible and would accept lower pay if conditions such as opportunities for advancement, health and safety at work etc. are met.
\end{abstract}

Keywords: corporate social responsibility (CSR), environment, business performance, performance factors

JEL Classification: F6; $Q 5, Z 1$

\footnotetext{
* Corresponding author: anica.hunjet@unin.hr
} 


\section{Introduction}

Businesses use human capital and resources, which tend to be limited, in the production of goods and services. Their activities release particles, substances and gases into the air, water and soil, many of which have a negative impact on the environment. To achieve their goals, organisations today need to consider the community and environment in which they operate. The concept of corporate social responsibility (CSR) implies activities such as providing support to the community and ethical behaviour in business. The paper investigates whether practicing corporate social responsibility can have positive impacts on the company's business and natural environment. The purpose of establishing a company is to generate profit. However, the environmental factor is increasingly recognised as one of the most important risk factors for the global economy. Air pollution, water scarcity and the degradation of natural capital have become credit, market and legal risks for businesses. This paper investigates the relationship between practicing CSR and business performance as well as the impact of CSR on the environment.

Kotler and Lee define corporate social responsibility or socially responsible business (SRB) as "a commitment to improve community well-being through discretionary business practices and contributions of corporate resources" [1].

Social responsibility implies investing in human capital and the environment, maintaining good relationships with stakeholders, and ethical behaviour in business with the aim of creating added value for the organisation and a more pleasant and healthier environment in general. The concept of social responsibility in relation to business has developed gradually so it cannot be determined precisely when it first emerged. With the development of industries that use human capital and natural resources to achieve their goals, i.e. profit, people started to become aware of the need to protect the environment as well as employees who contribute to the success of a particular industry $[2,3]$.

Corporate social responsibility provides a number of benefits for an organisation that has adopted this business practice. "However, managers are challenged at each of the fundamental decision points - decisions related to choosing a social issue, selecting an initiative to support this issue, developing and implementing program plans, and evaluating outcomes" [1].

Some social issues are easier to support than others, so deciding which social issue an organisation will choose is perhaps the biggest challenge as it affects subsequent programs and outcomes. Some of the questions faced by managers whose task is to choose a social issue include: How does the decision contribute to the business goals of the organisation?; How big of a social issue is this?; Is the government or someone else addressing the issue?; What will our shareholders think about the decision?; Will the decision on the social issue create a scandal $[4,5]$ ?

Once managers decide on a social issue, they must make a recommendation on what initiative - for example, community service, corporate philanthropy, corporate social marketing, and so on, would be useful in achieving the set social goal. This raises questions as to how an organisation can pursue a set social goal without putting at risk or neglecting its core business, whether these promotions really work, and who pays attention to them [6].

To achieve the goal, managers must adopt initiatives that support the social issue chosen. In their work "Corporate social responsibility", Kotler and Lee mention 6 ways in which a company does good:

1. Corporate cause promotions - support for growing concern and awareness for social causes.

2. Corporate social marketing - marketing campaigns aimed at behaviour change in society.

3. Cause-related marketing - contributions based on product sales.

4. Corporate philanthropy - contribution towards others in the community. 
5. Community service - employee volunteers.

6. Socially responsible business practices - day-to-day business based on increased social responsibility [1].

In his article "Pyramid of corporate social responsibility", Archie B. Carroll identified four areas that build the pyramid of corporate social responsibility. According to the author, this pyramid is a fundamental framework for understanding and implementing corporate social responsibility in business. The economic dimension is placed as the base of the pyramid which means that economic responsibility is the fundamental responsibility of a corporation, in other words, profitability is an imperative for any company. The next level is the legal dimension. Law is a social norm that defines acceptable and unacceptable behaviour, and an organisation should abide by the laws and regulations that apply to its business operations and market practices. The moral or ethical dimension requires that the company does what is fair and right. The organisation is expected to respect not only the legal framework (laws) but also human rights, and nurture a good relationship with the individual, society and natural environment. The philanthropic dimension imposes an obligation on the company to contribute through its business to the overall well-being of the people and community in which it operates, i.e. improve the quality of life $[7,8]$.

In the literature, two dimensions of socially responsible business are distinguished - the internal and external dimensions. The internal dimension of CSR includes human resources, health and safety, the ability to adapt to change, and the environment. The external dimension includes the local community, suppliers, customers and stakeholders in the organisation's operations $[9,10]$.

The internal dimension of corporate social responsibility refers to the social responsibility of the company towards its environment. It includes: human resource management, workplace health and safety, adaptation to change, and management of impacts on the environment and natural resources. The term human resources refers to the workforce within the company. They can be individuals within the company with their abilities or part of an organisation that deals with recruiting, terminating, training, and motivating employees, creating a positive work environment, assigning responsibilities, activities and tasks according to the employees' knowledge and skills and job requirements. Quality human resources can be a good source of competitive advantage for an organisation in the market. Respect for human rights and discouragement of any kind of discrimination will lower unemployment, demonstrate commitment to social issues, and improve labour market conditions, while good human resource management, in general, will reduce business costs and ensure business success. Workplace health and safety is primarily ensured by compliance with regulations and laws such as the Labour Act and the Occupational Safety and Health Act. In addition, organisations implement preventive measures by improving working conditions and safety at work. The demand for measuring, documenting and communicating these qualities in marketing materials is increasing. These elements are also included in certification and labelling [11-13].

The current dynamic market conditions require the organisations to adapt to new conditions in a socially responsible way so as to remain competitive in the market. In doing so, they must consider their goals, the interests of employees and all stakeholders in the business [11].

Given that natural resources are limited, they should be used efficiently. The organisation should minimise the negative impact of its business on the environment by saving energy, recycling, reducing emissions of harmful substances, particles and gases into the air, water and soil, using renewable alternatives whenever possible (for packaging - use of recycled packaging or in the case of energy - use of renewable energy sources in business operations). Such business practices will not only reduce negative environmental impacts but also lower operating costs (energy savings) [14]. 
The external dimension of CSR refers to corporate social responsibility practices outside the company, and includes the relationship with the local community, suppliers, customers and stakeholders. This relationship is reciprocal in that the organisation and actors in the external dimension influence one another to some extent.

The organisation influences the local community by providing employment opportunities thereby encouraging education, providing income for the local population, and attracting people from other areas if human resources with adequate competencies cannot be hired locally. It sponsors humanitarian actions, builds infrastructure thus facilitating the economic and social development of the community in which it operates [15].

Good relationships with business partners and suppliers are built on mutual trust, respect and compliance with contracts. Based on such relationships, the organisation can deliver a quality product to customers, which means deliver the right product, to the right place at the right time at the right price and, in doing so, achieve market success $[11,16]$.

In addition to the above, the external dimension includes respect for human rights, i.e. promotion of non-discrimination and equality in general as well as global care for the environment when organisations operate globally.

Socially responsible business involves, among other things, care for the environment and its governance. The environmental factor is increasingly emerging as one of the most important risk factors for the global economy. Air pollution, water scarcity and the degradation of natural capital have been shown to pose credit, market and legal risks to the economy. Natural capital is a good example. Natural capital is the world's supply of natural resources (water, soil, oil, air, forests and all living organisms). If a country has $75 \%$ of the world's supply of a mineral, it has a great advantage over other countries that produce the remaining $25 \%$, especially since natural capital is often limited [16]. However, natural capital requires unique maintenance compared to financial capital. For example, natural capital is often part of the ecosystem, so the harvesting, redistribution and changes to the natural capital can produce a ripple effect that can harm the company's environment and reputation. For example, land clearing can cause landslides and water pollution, or animal habitat destruction. It is also important to note that complete regeneration of natural capital is not possible.

Green finance is part of sustainable finance and refers to investments that contribute to the achievement of sustainable development goals. Effective environmental risk assessment is an integral part of the strategic approach to green finance, whose aim is to reduce risks. Corporate social responsibility can be divided into process stages: risk identification - which includes strategic assessment through predictive risk modelling, risk assessment - from a basic risk exposure assessment to detailed analysis of asset and portfolio risks, and risk management - activities to reduce exposure and mitigate or transfer risk and reroute an investment [17].

The CSR Index is a tool used for assessing corporate social responsibility in Croatia. It is based on a ranking system that allows an objective assessment of corporate social responsibility practices and comparison with other companies.

\section{Research methodology and results}

For the purpose of this paper, a survey was conducted in the period from 13-31 December 2019. A questionnaire created using the Google Forms tool was administered online - it was distributed via e-mail, social networks and private contacts. Participation was anonymous. 105 individuals completed the survey. The participants were mainly from the northern part of Croatia. After the survey, the collected data were analysed and presented graphically presented graphically as shown below [18]. 
The respondents' socioeconomic characteristics indicate that $73.3 \%$ are women and $26.7 \%$ are men. Most respondents (50.5\% of them) are in the age group 26-35, followed by the age group up to 25 (22.9\%). $18.1 \%$ are aged $36-45$, while $4.8 \%$ are in the $46-55$ age group. They are followed by respondents aged 56-65 (2.9\%) and those above 65 years of age (1\%).

Most respondents have secondary education (41\%), followed by those with completed graduate studies $(26.7 \%)$, undergraduate studies $(24.8 \%)$, postgraduate specialist studies $(3.8 \%)$, and doctoral studies $(2.9 \%)$. There are $1.9 \%$ of respondents whose formal education ended with primary school.

In terms of the respondents' employment status, $81.9 \%$ are employed, $11.4 \%$ are students, $3.8 \%$ are unemployed, $1.9 \%$ have retired, $1 \%$ have their own business and two $(2 \%)$ are on maternity leave.

When asked about their monthly income, the largest number of respondents $(41 \%)$ indicated that they earned between HRK 3,001-5,000. They are followed by $22.9 \%$ with a monthly income ranging from HRK 5,001 to HRK 7,000. A slightly lower percentage of respondents $(21 \%)$ have an income of more than HRK 7,000 per month. The smallest number of respondents $(15.2 \%)$ have a monthly income of less than HRK 3,000.

The respondents' attitudes and behaviour from the employee and customer perspectives are presented in the following paragraphs.

The respondents were asked to indicate the extent to which they agreed or disagreed with a given statement. There were 5 statements relating to the company in which the respondent worked. If the respondent was not employed at the time, he/she was asked to answer the questions drawing on their past experience. The answers were given on a scale of 1-5, where 1 means that the respondent completely disagrees, while 5 means that he/she completely agrees with a given statement.

To the question: "To what extent are the statements written below true for the company you work for?" the respondents answered as described below.

\section{The organisation in which the respondent works}

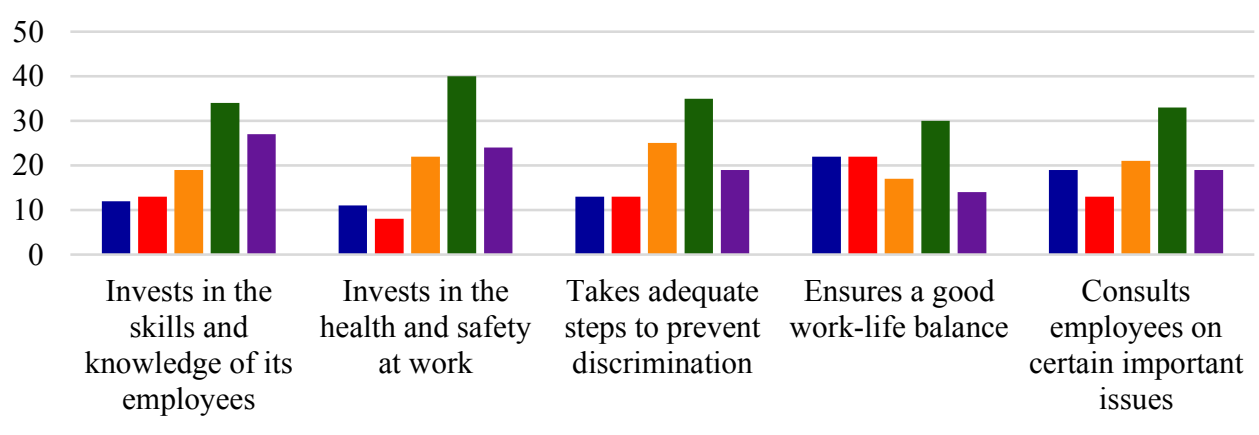

$\square$ Completely disagree $\square$ Disagree $\square$ Neither agree nor disagree $\square$ Agree $\square$ Completely agree

Fig. 1. Respondents' attitudes concerning the organisation in which they work(ed)

The first statement read "The organisation in which you work invests in the skills and knowledge of its employees". Most respondents (34) agreed with this statement while 27 of them completely agreed, indicating that this segment of CSR is being implemented in companies in Croatia. Furthermore, 19 respondents neither agreed nor disagreed, 13 respondents disagreed, while 12 of them completely disagreed with the mentioned statement. The second statement read "The organisation invests in the health and safety at work" The largest number of respondents (40) agreed, while 24 completely agreed with this statement. 22 respondents were undecided and chose the option "neither agree nor disagree", 8 
respondents did not agree with the statement, and 11 completely disagreed indicating that the organisation in which they (had) worked did not invest enough in the health and safety of its employees. The third statement read: "The organisation takes adequate steps to prevent discrimination". In this context, the term discrimination is used to mean workplace and employment discrimination. 35 respondents agreed with this statement, while 19 completely agreed. There was an equal number of those who disagreed and who completely disagreed with this statement (13). The fourth statement read: "The organisation ensures a good worklife balance". The largest share of respondents (30) agreed with that statement. However, in contrast to the previous statements, those who completely agreed with it were in the minority (only 14). 22 respondents disagreed and the same number of them completely disagreed with the statement. 33 respondents agreed with the next statement which read that the organisation: "consults employees on certain important issues". 19 respondents completely agreed, 21 neither agreed nor disagreed, 13 disagreed with it, while as many as 19 respondents completely disagreed with this statement.

To the question: "Would you agree to a lower salary if the company provided the above conditions or would you choose a higher salary over the described benefits?"

The majority of respondents $(60 \%)$ would settle for a lower salary if the described benefits were provided (opportunity to develop skills and knowledge at work, workplace health and safety, anti-discrimination policy, work-life balance, a sense of involvement in organisational decisions). $40 \%$ would prefer a higher salary.

The next question read: "To what extent do you contribute to the protection of the environment in your workplace?". Based on a number of statements, the respondents were asked to rate the extent of their contribution to the protection of the environment in their workplace on a scale of $1-5$, where 1 means "never" and 5 means "always".

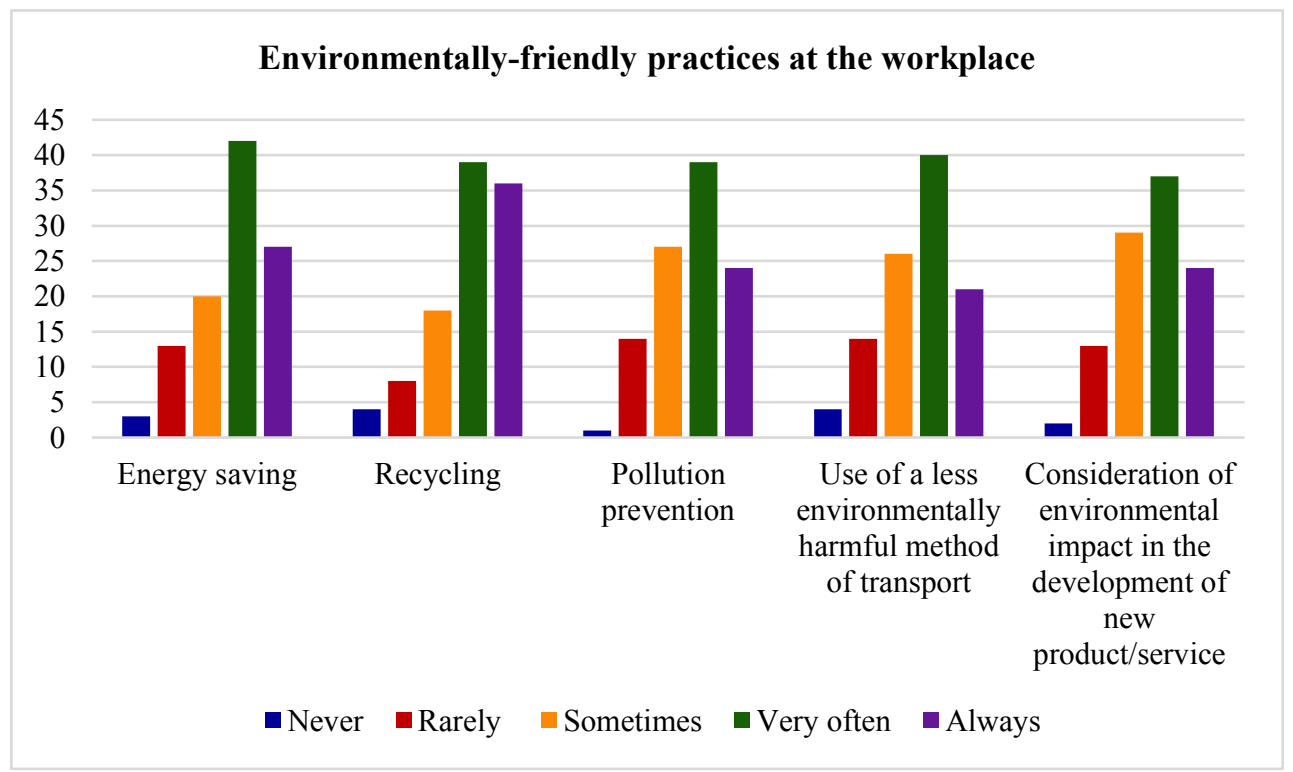

Fig. 2. Environmentally-friendly practices at the workplace

Several practices were examined. First, to what extent the respondents save energy in the workplace by, for instance, turning off the lights when leaving the room, turning off equipment when it is not being used, etc. The largest number of respondents (42) indicated that they did that "very often". 27 respondents answered "always", 20 respondents did that "sometimes", 13 respondents did it "rarely", while 3 indicated they "never" used any energy efficient practices at work. As for recycling, i.e. waste separation, the majority of respondents 
indicated that they recycled "always" (36) or "very often" (39). 18 respondents did it "sometimes", 8 did it "rarely", while 4 chose "never". When asked about their contribution to pollution prevention at work, i.e. the practice of preventing emissions of harmful substances into the air, water, etc., most respondents (39) answered they did that "very often", followed by 27 respondents who chose "sometimes", 24 who chose "always", 14 who said they did that "rarely", and one respondent who opted for "never". To the question whether they chose less environmentally harmful methods of transport when possible, the largest share of respondents (40) answered "very often", which suggests that there is awareness of the problem of environmental pollution and willingness to contribute to its prevention. 26 respondents indicated that they did that "sometimes", 21 did it "always", 14 respondents "very often" did not choose an environmentally-friendly method of transport, while 4 indicated "never" using a less environmentally harmful method of transport, even when it was readily available. 37 respondents confirmed that environmental impact is considered in the development of new product/service "very often". 29 respondents said that it was considered "sometimes", 24 answered "always", 13 chose "rarely", while 2 said that this was "never" done in their company.

The respondents were given two options to choose from as their preferred answer to the next question which asked: "Which statement best describes you?: I'd rather participate in a customer program where I get a toy whenever I buy a product, or I'd rather participate in a program where a donation is made to an environmental organisation with every purchase I make". The majority of respondents (75) indicated they would prefer a program that donates to an environmental organisation, while 30 respondents would choose the alternative.

To the question: "Would your reaction to a company that you think is not socially responsible be negative?", 89 respondents $(84.8 \%)$ indicated that their reaction would be negative, while 18 respondents $(17.1 \%)$ would not react negatively, i.e. would not stop using the products and services provided by that company.

Next, the respondents were asked to rate the importance of a particular corporate social responsibility practice in their decision to buy a company's products on a scale of $1-3$, where 1 means "not important" and 3 means "very important".

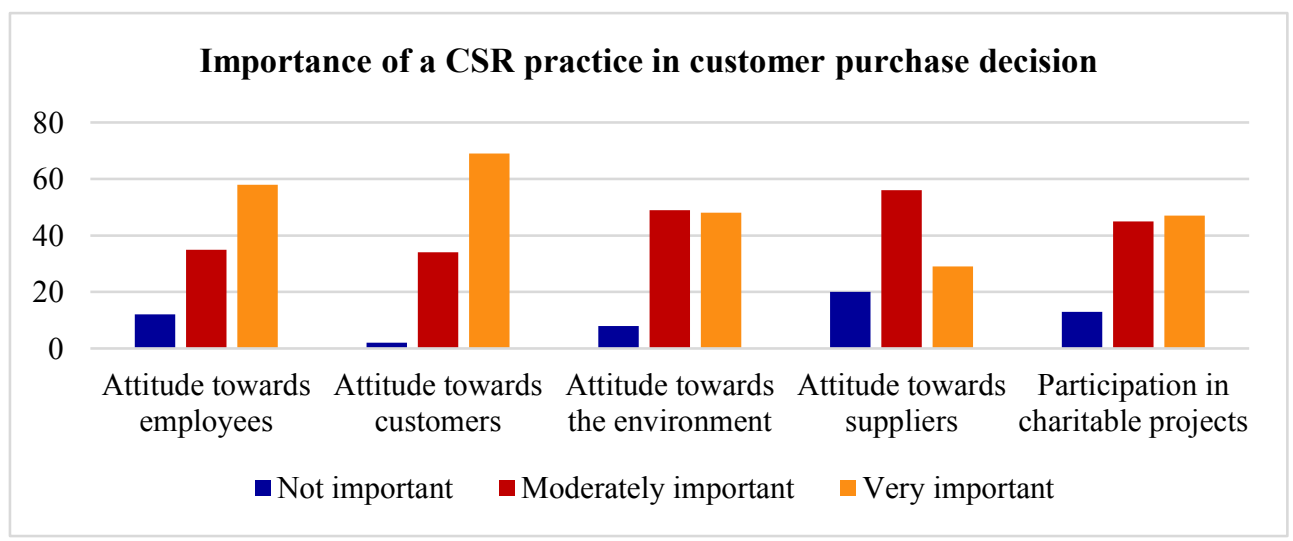

Fig. 3. Importance of a corporate social responsibility practice in customer purchase decision

Attitude towards employees is "very important" for 58 respondents. 35 respondents found it was "moderately important", and 12 respondents rated it as "not important". Attitude towards customers was found to be "very important" by the majority of respondents (69), for 34 respondents it is "moderately important", while 2 respondents reported that it was "not important" in their purchase decision. The number of respondents who found the company's attitude towards the environment "very important" and those who found it "moderately 
important" was very close, i.e. 48 and 49 respectively. Eight (8) respondents indicated that the company's attitude towards the environment was "not important" in their purchase decision. When asked to rate the importance of the company's attitude towards suppliers, most respondents (56) answered that it was a "moderately important" factor in their purchase decision. For 29 respondents, this practice is a "very important" factor and for 20 of them it is "not important". When asked to consider the company's participation in charitable projects from the perspective of the customer, 47 respondents rated this practice as a "very important" factor in their purchase decision, 45 indicated that it was "moderately important", while 13 respondents decided that such practice was "not important" in their decision to purchase a product or service provided by that organisation.

The next question asked: "Rate the importance of the following practices in your purchase decision".

The respondents were asked to rate the importance of a particular organisational practice in their purchase decision on a scale of 1-3, where 1 means "not important" and 3 means "very important".

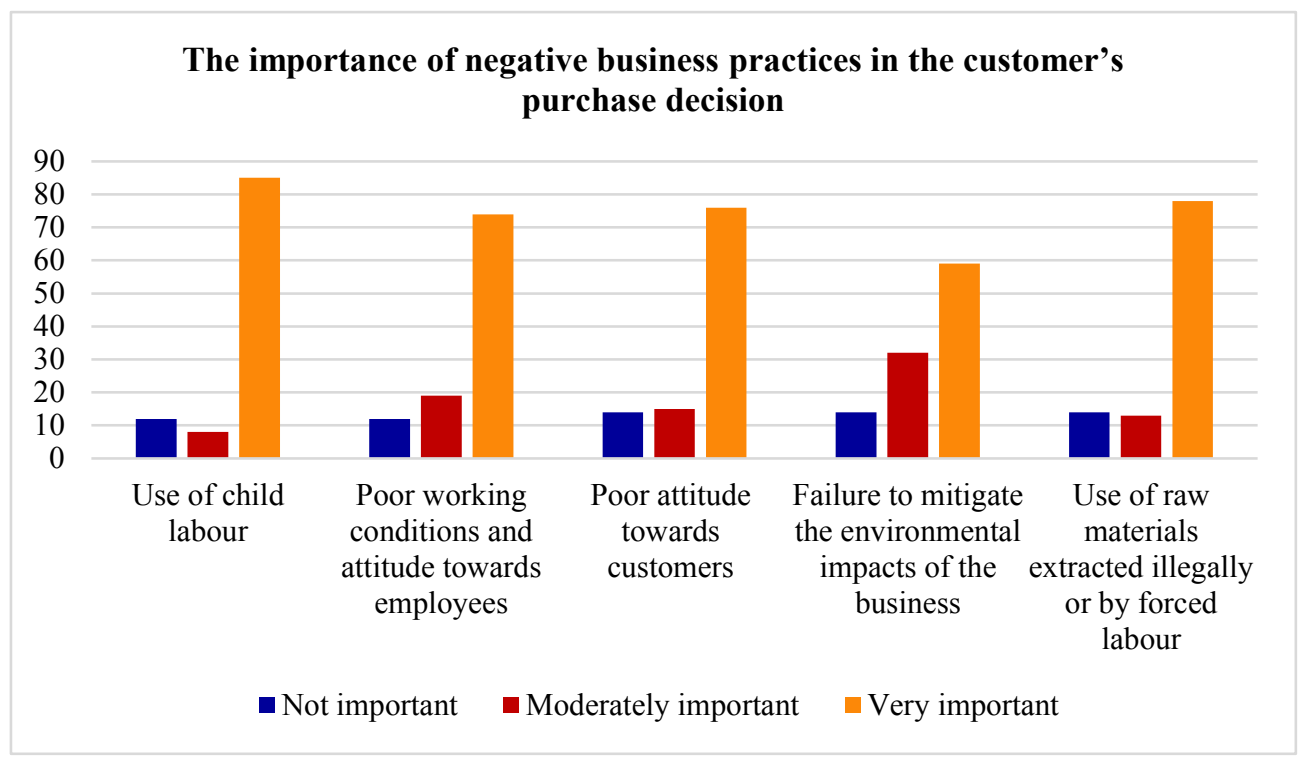

Fig. 4. The importance of negative business practices in the customer's purchase decision

This question analyses how the use of child labour would affect a company's reputation and the customer's purchase decision. 85 respondents answered that such practice would be a "very important" factor in their purchase decision. Eight (8) respondents reported that it would be a "moderately important" factor, while 12 respondents chose the option "not important". 74 respondents found that poor working conditions and poor attitude towards employees in the organisation would be a "very important" factor in their purchase decision. For 19 respondents, this practice would be "moderately important", while 12 respondents rated this factor as "not important". A poor attitude towards customers would be a "very important" factor in the customers' purchase decision, as indicated by 76 respondents. 15 respondents chose the option "moderately important", while 14 respondents thought their decision to purchase a company's product or service would not be affected by poor attitude towards customers as they selected the option "not important". All businesses affect the environment to some extent. When asked whether the fact that a company fails to mitigate the harmful effects of its business on the environment would affect their decision to purchase that company's products or services, 59 respondents indicated that that would play a "very 
important" role in their decision, for 32 respondents it would be "moderately important", while 14 respondents opted for "not important". In this study, 78 respondents indicated that the use of raw materials extracted illegally or by forced labour by a company would be a "very important" factor in their decision to purchase its products or services. For 13 respondents, that practice would be "moderately important", and the remaining 14 respondents found this factor to be "not important".

\section{Discussion}

A large number of organisations practice CSR (invest in skills and knowledge of their employees, workplace health and safety, and so on). However, a healthy work-life balance is not so frequently achieved and managers are less likely to consult with employees about specific issues, so companies need to focus more on these practices and improve them. The results of the survey indicate that the respondents, from the perspective of employees, prefer working in an organisation that practices social responsibility and would accept lower pay if opportunities for promotion, adequate health care and so on were provided. Regarding the use of environmentally-friendly practices at the workplace, it can be concluded that the situation is satisfactory as the respondents indicated that they had "often" or "very often" practiced socially responsible behaviour such as recycling, energy saving, etc. The obtained data suggest that people will gladly contribute to the protection of the environment if given the opportunity to do so and that they react positively to the companies that practice CSR. As the world's population is booming, our natural resources are becoming scarce. This is why non-economic factors are playing an increasingly important role in the buying process today - a trend which is likely to continue in the future. The respondents stated that they would not only be willing to pay more for a product/service provided by socially responsible organisations but would also appreciate them more. Specifically, $81.9 \%$ of the respondents stated that they would pay more for a product associated with a social cause. Furthermore, $80 \%$ of the respondents would switch to a brand that offers locally-sourced products at slightly higher prices. Among those, $48.6 \%$ would be willing to spend HRK 5-10 more for such a product. There are a number of benefits for an organisation that practices socially responsible behaviour, including increased sales and market share, increased brand awareness and recognition, improved corporate image and influence in the market, and attractiveness for both investors and new employees, thereby enhancing its ability to motivate and retain current employees. The results obtained by this research show that:

- $71.4 \%$ of the respondents would prefer to participate in a program where a donation is made to an environmental organisation with every purchase,

- $76.2 \%$ of the respondents base their impression of the organisation on its social responsibility,

- $84.8 \%$ of the respondents react negatively to a company that they believe is not socially responsible,

- $74.3 \%$ of the respondents would no longer buy products from an organisation that they believe has a poor attitude towards their people and the environment (does not implement CSR) even if the product is of high quality and affordable.

Based on the obtained data, it can be concluded that the participation of companies in social initiatives can affect the most important performance factors.

The main limitation of this study is the size of the sample. Given that it comprised 105 respondents from the northern part of Croatia, it is considered too small to provide meaningful results and not representative of the entire population of Croatia. 


\section{Conclusion}

Corporate social responsibility is a widely adopted and implemented concept in organisations around the world. The results of the present research indicate that organisations in Croatia are not lagging behind in this regard. The paper shows that, among other things, responsible behaviour towards society has an impact on the performance of an organisation, and the success must be shared with the community. An organisation is part of the community and as such it maintains mutually beneficial relationship with it. For example, employees are hired locally and they bring their knowledge, skills and abilities to the organisation. In return, the organisation looks after them so as to motivate them, keep their productivity flourishing, and reduce staff turnover. Not embracing CSR may have detrimental effects for both the community and the organisation in that it could increase unemployment and hinder companies from achieving their goals. Moreover, customers do not respond well to organisations that are not socially responsible, which leads to a decline in the sales of the organisation's products and services. Environmental neglect and failure to acknowledge that natural resources are limited and act accordingly puts at risk both the organisation and the environment. Organisations that implement socially responsible practices in their business are also more attractive to investors and other stakeholders.

By contributing to social causes, the organisation also helps its own business. Thus, the implementation of socially responsible behaviour should be viewed as an investment rather than expense.

\section{References}

1. Kotler, F.I., Lee, N. (2009). Društveno odgovorno poslovanje. Suvremena teorija i najbolja praksa. Zagreb: MEP consult.

2. Bobera, D., Hunjet, A., Kozina, G. (2015) Poduzetništvo. Varaždin: Sveučilište Sjever.

3. Hunjet, A., Kozina, G. (2014). Osnove poduzetništva. Varaždin: Sveučilište Sjever.

4. Tamvada, M. (2020). Corporate social responsibility and accountability: a new theoretical foundation for regulating CSR. International Journal of Corporate Social Responsibility, 5, Art. No. 2.

5. Čutura, M. (2018). Marketing dionika: prema boljem razumijevanje društvene odgovornosti marketinga. Ekonomska misao i praksa, 1, 141-156

6. Licandro, O. (2017). The relationship between corporate volunteering and corporate social responsibility: results of an empirical study. Ekonomski vjesnik: Review of Contemporary Entrepreneurship, Business, and Economic Issues, 30(1), 67-83.

7. Carroll, A.B. (2016). Carroll's Pyramid of CSR: Taking another look. International Journal of Corporate Social Responsibility, 1(1), 1-8.

8. Servera-Francés, D., Piqueras-Tomás, L. (2019). The effects of corporate social responsibility on consumer loyalty through consumer perceived value. Economic research - Ekonomska istraživanja, 32(1), 66-84.

9. Kim, W.S., Oh, S. (2019). Corporate social responsibility, business groups and financial performance: a study of listed Indian firms. Economic research - Ekonomska istraživanja, 32(1), 1777-1793.

10. Moisescu. O.I. (2018). From perceptual corporate sustainability to customer loyalty: a multi-sectorial investigation in a developing country. Economic research - Ekonomska istraživanja, 31(1), 55-72. 
11. Vučemilović, V. (2019). Correlation between the internal elements of the corporate social responsibility concept. Ekonomski vjesnik, 2, 449-459.

12. Mohammadi, M.A.D., Mardani, A., Khan, M.N.A., Streimikiene, D. (2018). Corporate sustainability disclosure and market valuation in a Middle Eastern Nation: evidence from listed firms on the Tehran Stock Exchange: sensitive industries versus non-sensitive industries. Economic research - Ekonomska istraživanja, 31(1), 1488-1511.

13. Rodríguez, G.P., Valiño, C.P., Vázquez Burguete, J.L. (2017). The effects of corporate social responsibility on customer-based brand equity: Spanish hypermarket case. Economic research - Ekonomska istraživanja, 30(1), 290-301.

14. Vrdoljak Raguž, I., Hazdovac, K. (2014). Društveno odgovorno poslovanje i hrvatska gospodarska praksa. Oeconomica Jadertina, 4(1), 40-58.

15. Galant, A., Cadez, S. (2017). Corporate social responsibility and financial performance relationship: a review of measurement approaches. Economic research - Ekonomska istraživanja, 30(1), 676-693.

16. Kolić Stanić, M., Barišić, A.F. (2019). Social Responsibility and Loyalty in Public Relations Codes. Business Systems Research: International journal of the Society for Advancing Innovation and Research in Economy, 10(2), 151-162.

17. Barkman,A. (2018, September 18). Europska agencija za okoliš, Ulaganje-u-svrhuodrzivosti. Retrieved from: https://www.eea.europa.eu/hr/articles/ulaganje-u-svrhuodrzivosti

18. Petz, B. (2012). Osnovne statističke metode za nematematičare, Naklada Slap, Zagreb. 